\title{
Effects of paralytic shellfish toxins on the middle intestine of Oncorhynchus mykiss: Glutathione metabolism, oxidative status, lysosomal function and ATP-binding cassette class $\mathrm{C}$ (ABCC) proteins activity
}

\author{
Julio C. Painefilú ${ }^{\text {a }}$, Virginia A. Bianchi ${ }^{\text {a }}$, Bernd Krock ${ }^{b}$, Julieta S. De Anna ${ }^{\text {a }}$, Gisela Kristoff ${ }^{\text {c,d }}$, \\ Carlos M. Luquet ${ }^{\text {a, }}$ \\ ${ }^{a}$ Laboratorio de Ecotoxicología Acuática, Subsede INIBIOMA-CEAN (CONICET-UNCo), ruta provincial 61, km 3, CCP 7, Junín de los Andes, 8371, Neuquén, Argentina \\ b Ökologische Chemie, Alfred Wegener Institut-Helmholtz Zentrum für Polar- und Meeresforschung, Am Handelshafen 12, 27570, Bremerhaven, Germany \\ ${ }^{\mathrm{c}}$ Laboratorio de Ecotoxicología Acuática Invertebrados Nativos, Departamento de Química Biológica, IQUIBICEN (CONICET-UBA), Facultad de Ciencias Exactas y \\ Naturales Universidad de Buenos Aires, Ciudad Universitaria, Intendente Güiraldes, 2160, CABA, Argentina \\ d Departamento de Química Biológica, Facultad de Ciencias Exactas y Naturales, Universidad de Buenos Aires, Ciudad Universitaria, Intendente Güiraldes, 2160, CABA, \\ Argentina
}

\section{A R T I C L E I N F O}

\section{Keywords:}

Saxitoxin

Multixenobiotic resistance

ABCC

Lysosomal membrane

Toxicokinetics

Rainbow trout

\begin{abstract}
A B S T R A C T
We studied the absorption, cytotoxicity and oxidative stress markers of Paralytic Shellfish Toxins (PST) from three extracts from Alexandrium catenella and A. ostenfeldii, in middle Oncorhynchus mykiss intestine in vitro and ex vivo preparations. We measured glutathione (GSH) content, glutathione-S transferase (GST), glutathione reductase (GR) and catalase (CAT) enzymatic activity, and lipid peroxidation in isolated epithelium exposed to 0.13 and $1.3 \mu \mathrm{M}$ PST. ROS production and lysosomal membrane stability (as neutral red retention time $50 \%$, NRRT50) were analyzed in isolated enterocytes exposed to PST alone or plus $3 \mu \mathrm{M}$ of the ABCC transport inhibitor MK571. In addition, the concentration-dependent effects of PST on NRRT50 were assayed in a concentration range from 0 to $1.3 \mu \mathrm{M}$ PST. We studied the effects of three different PST extracts on the transport rate of the ABCC substrate DNP-SG by isolated epithelium. The extract with highest inhibition capacity was selected for studying polarized DNP-SG transport in everted and non-everted intestinal segments. We registered lower GSH content and GST activity, and higher GR activity, with no significant changes in CAT activity, lipid peroxidation or ROS level. PST exposure decreased NRRT50 in a concentration-depend manner (IC50 $=0.0045 \mu \mathrm{M}$ ), but PST effects were not augmented by addition of MK571. All the three PST extracts inhibited ABCC transport activity, but this inhibition was effective only when the toxins were applied to the apical side of the intestine and DNP-SG transport was measured at the basolateral side. Our results indicate that PST are absorbed by the enterocytes from the intestine lumen. Inside the enterocytes, these toxins decrease GSH content and inhibit the basolateral ABCC transporters affecting the normal functions of the cell. Furthermore, PST produce a strong cytotoxic effect to the enterocytes by damaging the lysosomal membrane, even at low, non-neurotoxic concentrations.
\end{abstract}

\section{Introduction}

Paralytic shellfish toxins (PST) are neurotoxic compounds that inhibit voltage-gated sodium channels interrupting the action potential in nerve and muscle cells (Catterall, 1980, for a review). PST comprise several structural variants, such as saxitoxin (STX), sulfated gonyautoxins (GTX) and $N$-sulfocarbamoyl toxins (B- and C-toxins), of which STX is the most neurotoxic one (Thottumkara et al., 2014). These compounds are produced by marine dinoflagellates and freshwater cyanobacteria (Lagos, 2003, for a review; Kellmann et al., 2013), and can reach high levels in blooms or surface scums, which can particularly affect the use of water for tap water production, aquaculture and recreational activities (Testai et al., 2016a, for a review). PST may be accumulated in aquatic organisms and incorporated into the trophic chain (Ferrão-Filho and Kozlowsky-Suzuki, 2011; Lopes et al., 2014; Madigan et al., 2018; Suárez-Isla, 2016). In fish, besides neuromotor effects (Bakke and Horsberg, 2007; Bakke et al., 2010; Lefebvre et al., 2004), PST can produce oxidative stress (Clemente et al., 2010; da Silva et al., 2011) and lethal effects (Montoya et al., 1997; White, 1980).

\footnotetext{
* Corresponding author.

E-mail address: luquetc@comahue-conicet.gob.ar (C.M. Luquet).
} 

Abbreviations
ABCC ATP-binding cassette class $\mathrm{C}$ protein
CAT Catalase
CDNB 1-chloro-2,4-dinitrobenzene
DCFDA 2,7-dichlorofluorescein diacetate
DMSO Dimethyl sulfoxide
DNP-SG (dinitrophenyl-S-glutathione)
DTNB 5,5'-dithiobis (2-nitrobenzoic acid)
EDTA Ethylenediaminetetraacetic acid
GR Glutathione reductase
GSH Glutathione
GSSG Glutathione disulfide
GST Glutathione-S-transferase
NADPH Nicotinamide adenine dinucleotide phosphate
NRRT50 Neutral Red Retention Time 50\%
PST Paralytic Shellfish Toxins
ROS Reactive Oxygen Species
Tris Tris(hydroxymethyl) aminomethane

and drinking, both, the permeability and the biotransformation-excretion capacity of the intestinal epithelium are critical for absorption of toxins and toxicity. However, despite that excretion of some voltage-gated sodium channel blockers such as oxaliplatin through ABCCs has been studied (Grolleau et al., 2001; Myint et al., 2019), there is no report on the involvement of these transporters on elimination of PST.

Besides being widely used as model species for physiological and toxicological experiments, the rainbow trout $O$. mykiss is the principal aquaculture resource in Argentina, where most of the production takes place in freshwater reservoirs of North Patagonia. In these environments, there are frequent blooms of potentially PST- and microcystinproducing cyanobacteria of the genus Dolichospermum. Studies of our laboratory have analyzed the toxicity and cellular transport of cyanotoxins and arsenite in intact fish and in ex vivo preparations of $O$. mykiss intestine and liver (Bieczynski et al., 2014; Painefilú et al., 2019).

The aim of this work was to evaluate the absorption and intracellular effects of PST in intestinal epithelial cells of $O$. mykiss middle intestine by measuring lysosomal membrane stability, ROS production, GSH content, GR and GST activity, and lipid peroxidation. Furthermore, we studied the interaction between PST and the MXR system through ABCC transport experiments in ex-vivo and in vitro preparations.

The highest amounts of these toxins are mostly found in gut content and liver (Deeds et al., 2008) although accumulation of PST in muscle has been reported to occur in two freshwater fish species used for human consumption, the Nile tilapia (Oreochromis niloticus) (Galvão et al., 2009) and Geophagus brasiliensis (Calado et al., 2020). Therefore, it is important to know the capacity of fish used in aquaculture for biotransformation and excretion of PST, in order to avoid possible risks of human poisoning (Etheridge, 2010). For example, the Atlantic salmon (Salmo salar) and the Atlantic cod (Gadus morhua) can excrete PST from their organs (Bakke and Horsberg, 2010), but the biotransformation and excretion mechanisms involved are not clear yet.

The biotransformation of PST has been reported to occur in bacteria, marine invertebrates and mammals (García et al., 2010, 2004), through chemical reactions that include glucuronidation, oxidation, epimerization and reduction (Bricelj and Shumway, 1998, for a review; Lukowski et al., 2019). Fish like white seabream (Diplodus sargus) are able to biotransform the $N$-sulfocarbamoyl PST analogues, incorporated through the diet, into B1 and decarbamoyl saxitoxin (dcSTX) (Costa et al., 2011). This kind of biotransformation was reported to occur in bivalves and bacteria, in the presence of thiols like those present in the tripeptide glutathione (GSH) (Asakawa et al., 1987; Sakamoto et al., 2000; Sato et al., 2000). These reactions can include conjugation with GSH catalyzed by enzymes of the glutathione-S-transferase family (GST) and/or toxin reduction coupled to GSH oxidation to GSSG. In turn, GSH levels can be rapidly restored by reduction of GSSG catalyzed by the enzyme glutathione reductase (GR). PST can induce GST activity in fish, which suggests the participation of this enzyme in their biotransformation (Costa et al., 2012; Gubbins et al., 2000).

It has been widely shown that GSH-conjugated xenobiotics are more easily detoxified than the original molecules (Schlenk et al., 2008; Parkinson and Ogilvie, 2008), in the context of the multixenobiotic resistance (MXR) system, the aquatic species' analog of the multidrug resistance of mammals (MDR), first described for chemotherapy resistance in cancer cells (Kurelec, 1992; Bard, 2000). This system involves the active extrusion of a wide range of compounds by membrane proteins of the ATP-binding cassette family. Many xenobiotic and endobiotic compounds are conjugated with GSH and then exported from the cell through ATP-binding cassette class C (ABCC) transporters (Epel et al., 2008; Omiecinski et al., 2011, for a review). For example, the cyanotoxin microcystin-LR and arsenite have been shown to be detoxified through this mechanism in the middle intestine of Oncorhynchus mykiss and Odontesthes hatchery (Bieczynski et al., 2014, 2016; Painefilú et al., 2019). Since fish are in contact with PST mainly through the diet

\section{Materials and methods}

\subsection{Chemicals}

1-chloro-2,4-dinitrobenzene (CDNB), MK571 sodium salt hydrate, glutathione (GSH), 5,5'-dithiobis (2-nitrobenzoic acid) (DTNB), Dithiothreitol, Bovine serum albumin, Nicotinamide adenine dinucleotide phosphate (NADPH), Neutral red, Trypan blue, $2^{\prime}, 7^{\prime}$-dichlorofluorescein diacetate (DCFDA) and butylhydroxytoluene were purchased from Sigma (USA). Tris (hydroxymethyl) aminomethane (Tris) was purchased from Serva (Germany). 5-Sulfosalicylic acid was purchased from Mallinckrodt Chemicals (Ireland). Folin Ciocalteu reagent was purchased from Biopack (Argentina). Ethylenediaminetetraacetic acid (EDTA) and acetic acid were purchased from Cicarelli (Argentina). Glutathione disulfide (GSSG) was purchased from Santa Cruz Biotechnology (USA). Trichloroacetic acid and Thiobarbituric acid were purchased from Merck (Germany). Dimethyl sulfoxide (DMSO) was purchased from Anedra (Argentina). Sodium citrate $\left(\mathrm{Na}_{3} \mathrm{C}_{6} \mathrm{H}_{5} \mathrm{O}_{7}\right)$ was purchased from Stanton (Argentina). Lysing matrix D was purchased from MP Biomedicals (USA).

\subsection{Paralytic shellfish toxin extracts}

PST were extracted from cultures of Alexandrium catenella (PST 1) and Alexandrium ostenfeldii (PST2 and PST3) (Table 1). The cell pellet

Table 1

Relative Paralytic Shellfish Toxin (PST) profiles of the extracts used in the experiments. Total PST concentrations are expressed as $\mu \mathrm{g}$ saxitoxin toxicity equivalents $\mathrm{L}^{-1}$ ( $\mu$ g STXeq $\left.\mathrm{L}^{-1}\right)$, $\mu \mathrm{mol}$ saxitoxin toxicity equivalents $\mathrm{L}^{-1}(\mu \mathrm{mol}$ STXeq $\mathrm{L}^{-1}$ ), according to FAO/WHO (2016), and as $\mu$ mol PST $\mathrm{L}^{-1}$.

\begin{tabular}{|c|c|c|c|c|}
\hline & \multirow{2}{*}{$\frac{\text { A. catenella }}{\text { PST1 }}$} & \multicolumn{2}{|c|}{ A. ostenfeldii } & \multirow{2}{*}{$\begin{array}{l}\text { Molecular weight (g } \\
\mathrm{mol}^{-1} \text { ) }\end{array}$} \\
\hline & & PST2 & PST3 & \\
\hline $\mathrm{C} 1 / \mathrm{C} 2$ & 35.13 & 92.64 & 87.79 & 475.40 \\
\hline GTX1/4 & 39.19 & 0.00 & 0.00 & 411.35 \\
\hline GTX2/3 & 0.27 & 0.00 & 5.23 & 395.35 \\
\hline B1 & 0.03 & 1.23 & 1.16 & 379.35 \\
\hline NEO & 23.67 & 0.00 & 0.00 & 315.29 \\
\hline STX & 1.61 & 6.13 & 5.82 & 299.29 \\
\hline Total $\left(\mu \mathrm{g}\right.$ STXeq $\left.\mathrm{L}^{-1}\right)$ & 37.39 & 5.65 & 5.47 & \\
\hline $\begin{array}{l}\text { Total }(\mu \text { mol STXeq } \\
\left.\mathrm{L}^{-1}\right)\end{array}$ & 0.11 & 0.016 & 0.015 & \\
\hline Total $\left(\mu \mathrm{mol}\right.$ PST L $\left.\mathrm{L}^{-1}\right)$ & 0.13 & 0.11 & 0.11 & \\
\hline
\end{tabular}


was lysed with $500 \mu \mathrm{L}$ of $0.03 \mathrm{~N}$ acetic acid and $0.9 \mathrm{~g}$ lysing matrix D in a sample disruption instrument (FastPrep ${ }^{\circledR}$, Thermo Savant, Illkirch, france) and homogenized by reciprocal shaking at $6.5 \mathrm{~ms}^{-1}$ for $45 \mathrm{~s}$. After this, samples were centrifuged at $16,100 \times g$ at $4{ }^{\circ} \mathrm{C}$, for $15 \mathrm{~min}$. The supernatant was filtered $(0.45 \mu \mathrm{m}$ pore size) and centrifuged at $800 \times g$ for $30 \mathrm{~s}$. The toxins contained in the extract were determined by HPLC/ FLD with post-column derivatization (Column: Phenomenex Luna C18, $5 \mu \mathrm{m}, 250 \times 4.6 \mathrm{~mm}$ ) a detailed in Van de Waal et al. (2015).

\subsection{Fish and experimental models}

O. mykiss individuals $(280 \pm 40 \mathrm{~g})$ were maintained in tanks with circulating freshwater $\left(\mathrm{T}^{\circ}=17 \pm 3.6^{\circ} \mathrm{C}, \mathrm{pH}=7.13 \pm 0.7, \mathrm{DO}=9.84 \pm\right.$ $0.24 \mathrm{mg} \mathrm{L}^{-1}$ ) from Chimehuin river, in the Centro de Ecología Aplicada del Neuquén (CEAN, Argentina). Fish were fasted for $24 \mathrm{~h}$ before sacrificed by a blow to the head and decapitation. The middle intestine was removed, rinsed in Cortland solution and used for obtaining intestinal segments, isolated epithelium or isolated enterocytes. For all these preparations, the intestine of each individual was used to obtain the control and the treated preparations. Six to nine individuals were used for each experiment. These experimental protocols were approved by the Bioethics Committee, Faculty of Biochemical and Pharmaceutical Sciences, National University of Rosario, Argentina (6060/116).

The use of different experimental models allowed the measurement of a broad range of variables with more realistic to more detailed approaches. The intestinal segments allow to maintain the epithelium polarity to differentiate apical from basolateral transport. We used the isolated epithelium in ex vivo assays to avoid any interference from the sub-epithelial muscle layers and to obtain sensitive responses. Finally, the isolated enterocytes allowed the determination of reactive oxygen species (ROS) levels and lysosomal membrane stability.

\subsubsection{Intestinal segments}

According to Bieczynski et al. (2014), to prepare paired everted and non-everted preparations, the middle intestine was separated and cut into two transversal segments (one for control and the other for the treatment), weighed, ligated at both ends and filled with Cortland solution with a Teflon cannula attached to a Hamilton syringe. For the everted preparations, the segment was everted by sliding a crochet needle inside the intestine tube.

\subsubsection{Isolated epithelium}

The middle intestine was opened longitudinally and cut into strips. From each strip, the epithelial layer was separated from the muscular layer with a $170 \mu \mathrm{m}$ thick PVC sheet. The isolated epithelium was incubated with PST according to the variable to be measured. After each incubation, the epithelium was put in ice-cold homogenization buffer (Tris $40 \mathrm{mM}$; KCl $150 \mathrm{mM}$; $0.5 \mathrm{mM}$ EDTA), pH 8.6, and homogenized with a Cole-Parmer LabGen 7 homogenizer at 35,000 rpm. Homogenates were centrifuged at $9700 \times g$ for $15 \mathrm{~min}$ at $4{ }^{\circ} \mathrm{C}$ and supernatants were used for determinations.

\subsubsection{Isolated enterocytes}

Enterocytes were isolated according to the protocol described by Kwong and Niyogi (2012), with slight modifications. The middle intestine was cut into strips and incubated for $5 \mathrm{~min}$ in $5 \mathrm{~mL}$ of citrate buffer (pH 7.4) and $20 \mathrm{~min}$ in $5 \mathrm{~mL}$ of isolation buffer (154 mM NaCl, $10 \mathrm{mM}$ $\mathrm{Na}_{2} \mathrm{HPO}_{4}, 2 \mathrm{mM}$ EDTA, $2 \mathrm{mM}$ dithiothreitol, $5.5 \mathrm{mM}$ glucose, $\mathrm{pH}$ 7.4). After this, enterocytes were removed from the muscular layer using a cell scraper and the clumped cells were carefully dispersed using a plastic pipette. The suspension was filtered through a $200 \mu \mathrm{m}$ polyester mesh and centrifuged at $600 \times g$ for $4 \mathrm{~min}$, at $4{ }^{\circ} \mathrm{C}$. The pellet was washed and centrifuged 3 times using Cortland solution in order to remove the isolation buffer, and then resuspended in Cortland solution and filtered through a $75 \mu \mathrm{m}$ polyester mesh. Cell viability and density were checked using the trypan blue $(0.1 \%)$ exclusion method, in a Neubauer chamber under a light microscope. Cell viability after the procedure was always higher than $90 \%$.

\subsection{Intracellular effects}

\subsubsection{Protein content in isolated epithelium}

The results of the experiments conducted with isolated epithelium were referred to total soluble protein, which was the standardization variable with lowest variability in preliminary assays. Total protein content was measured in the supernatant of epithelium homogenates by the method of Lowry et al. (1951), using bovine serum albumin as standard and were expressed as $\mathrm{mg}$ protein $\mathrm{mL}^{-1}$.

\subsubsection{Glutathione and associated enzymes}

We measured GSH content, GST activity, and glutathione reductase (GR) activity in isolated epithelium incubated for $1 \mathrm{~h}$ in glass vials with $3 \mathrm{~mL}$ of Cortland solution alone or plus $0.13 \mu \mathrm{M}\left(50 \mu \mathrm{g} \mathrm{L}{ }^{-1}\right)$ or $1.3 \mu \mathrm{M}$ $\left(500 \mu \mathrm{g} \mathrm{L}^{-1}\right.$ ) PST1. These concentrations were defined according to cellular PST contents and cell numbers reported for several dinoflagellate blooms (Cembella et al., 2002; Sephton et al., 2007; Testai et al., 2016a; for a review).

GSH content was measured according to Ellman's method (1959), modified by Venturino et al. (2001). Supernatants (section 2.3.2) were deproteinized by treatment with $5 \%$ sulfosalicylic acid, final concentration and centrifuged at $6700 \times g$ for $10 \mathrm{~min}$. These supernatants were incubated for $5 \mathrm{~min}$ with $2 \mathrm{mM}$ DTNB, final concentration, in $250 \mathrm{mM}$ phosphate buffer, $\mathrm{pH} 8$, and absorbance was read at $412 \mathrm{~nm}$. The results were expressed in nmol GSH mg protein ${ }^{-1}$.

GST activity was measured according to Habig et al. (1974). The absorbance was measured through $180 \mathrm{~s}$ in $100 \mathrm{mM}$ phosphate buffer, pH 6.5, with $100 \mathrm{mM} \mathrm{GSH}$ and $100 \mathrm{mM}$ CDNB as substrates. Activity was expressed in $\mathrm{nmol} \mathrm{s}^{-1} \mathrm{mg}_{\text {protein }}^{-1}$.

GR activity was measured according to Schaedle and Bassham (1977), with modifications. Absorbance was read at $340 \mathrm{~nm}$ for $300 \mathrm{~s}$ in $143 \mathrm{mM}$ phosphate buffer plus $6.3 \mathrm{mM}$ EDTA, pH 7.5, with $0.13 \mathrm{mM}$ NADPH and $10 \mathrm{mM}$ GSSG as substrates. The activity was expressed in $\mathrm{nmol} \mathrm{s} \mathrm{m}^{-1} \mathrm{mg}$ protein ${ }^{-1}$.

\subsubsection{Oxidative stress biomarkers}

We measured catalase (CAT) activity and lipid peroxidation in supernatants of homogenates from isolated epithelium (section 2.3.2) incubated for $1 \mathrm{~h}$ in glass vials with $3 \mathrm{~mL}$ of Cortland solution alone or plus $0.13 \mu \mathrm{M}$ or $1.3 \mu \mathrm{M}$ of PST1 extract and ROS production in isolated enterocytes (section 2.3.3) incubated for $1 \mathrm{~h}$ in glass vials with $1 \mathrm{~mL}$ of Cortland solution alone, plus $0.13 \mu \mathrm{M}$ PST1 extract, or plus $0.13 \mu \mathrm{M}$ PST1 extract with $3 \mu \mathrm{M}$ MK571.

CAT activity was measured according to Aebi (1984), with modifications. Absorbance was read at $240 \mathrm{~nm}$ for $30 \mathrm{~s}$ in $50 \mathrm{mmol} \mathrm{L}^{-1}$ phosphate buffer, pH 7 with $0.3 \mathrm{M} \mathrm{H}_{2} \mathrm{O}_{2}$ as substrate. Activity was expressed in nmol s${ }^{-1} \mathrm{mg}_{\text {protein }}{ }^{-1}$.

Lipid peroxidation was measured according to Fraga et al. (1988) by the thiobarbituric acid reactive substances (TBARS) method. Absorbance was read at $532 \mathrm{~nm}$ in a reaction mixture with $26 \mathrm{mM}$ thiobarbituric acid, $2 \% \mathrm{HCl}, 15 \%$ trichloroacetic acid and $100 \mathrm{mM}$ butylhydroxytoluene. The results were expressed as $\mu \mathrm{mol} \mathrm{mg} \mathrm{protein}{ }^{-1}$.

ROS production was measured according to Amado et al. (2009) and Moss and Bassem (2006), with modifications. A suspension of isolated enterocytes $\left(10^{5}\right.$ viable cells $\left.\mathrm{mL}^{-1}\right)$ was added to the reaction buffer (30 mM Hepes, $200 \mathrm{mM} \mathrm{KCl,} 1 \mathrm{mM} \mathrm{MgCl}_{2}, \mathrm{pH} 7.2$ ), with $40 \mu \mathrm{M}$ DCFDA as substrate. Fluorescence was recorded in a Qubit fluorometer (Invitrogen, USA) at $485 / 530 \mathrm{~nm}$ for $60 \mathrm{~min}$. Fluorescence units measured along time were adjusted to a second order polynomial function and the area under the curve (AUC) was calculated and standardized to $5 \times 10^{4}$ viable cells $\mathrm{mL}^{-1}$ (Amado et al., 2009). Data are shown as percentage of the control. 


\subsubsection{Lysosomal membrane stability}

Isolated enterocytes $\left(10^{6}\right.$ viable cells $\mathrm{mL}^{-1}$, final concentration) were incubated for $1 \mathrm{~h}$ in glass vials with $0.5 \mathrm{~mL}$ of Cortland solution and PST1 at seven increasing concentrations from 0 to $1.3 \mu \mathrm{M}$. Then, the lysosomal membrane stability was evaluated using the Neutral Red Retention Time assay (NRRT50), according to Mamaca et al. (2005) and Dayeh et al. (2003), with modifications. After incubation with PST, the isolated enterocytes were incubated with $66 \mu \mathrm{M}$ (final concentration) neutral red dye for $5 \mathrm{~min}$. Each sample was observed under a light microscope and the number of red stained cells was counted every $10 \mathrm{~min}$, until reaching $50 \%$ of the total cells. The results were expressed as neutral red retention time 50\% (NRRT50, min). Data were adjusted to a non-linear regression analysis of NRRT50 (as percentage of the control) vs. $\log$ PST concentration.

\subsection{ABCC activity}

The experiments of this section are based on that CDNB is a membrane permeant compound, which diffuses into the cell, where it is conjugated with GSH in a reaction catalyzed by GST. The conjugation product, dinitrophenyl-S-glutathione (DNP-SG) is exported by ABCC proteins from the cell to the external bath, where it is detected spectrophotometrically (Fig. 1).

\subsubsection{DNP-SG transport in isolated epithelium}

We studied the effects of three PST extracts (PST1, PST2 and PST3) on DNP-SG transport rate in isolated intestinal epithelium. We incubated isolated epithelium strips in glass vials with $3 \mathrm{~mL}$ of Cortland solution plus $200 \mu \mathrm{M}$ of CDNB. All PST extracts were applied at final concentrations of $0.13 \mu \mathrm{M}$ for PST1 and $0.11 \mu \mathrm{M}$, for PST2 and PST3. These concentrations are equivalent to $50 \mu \mathrm{g} \mathrm{L}^{-1}$ for all extracts. Transport rate results were expressed as nmol DNP-SG mg protein ${ }^{-1} \mathrm{~min}^{-1}$.

\subsubsection{DNP-SG transport in intestinal segments}

The effects of PST on the apical (luminal) and basolateral DNP-SG transport were studied in paired everted and non-everted intestinal segments, respectively. In both types of preparation, the PST were applied either at the apical or at the basolateral side, in order to study the permeability of both membranes to PST. In all cases, CDNB was added in the bathing solution (Fig. 1). PST2 was selected for this experiment because it was the most effective in the previous experiment with isolated epithelium.

DNP-SG absorbance was measured at $340 \mathrm{~nm}$ every $10 \mathrm{~min}$ for $1 \mathrm{~h}$ and the DNP-SG transport rate was calculated as the slope of a cumulative absorbance $v$ s. time plot, and using an extinction coefficient of 9.6 $\mathrm{mM} \mathrm{cm}{ }^{-1}$. The transport rate was normalized to wet tissue mass and the result for each individual was calculated as percentage of the corresponding control. The specificity of the assay for DNP-SG transport was previously confirmed in similar preparations by HPLC analysis (Bieczynski et al., 2014).

\subsubsection{Effects of ABCC transport inhibition on PST cytotoxicity}

In order to investigate whether PST are exported by ABCC transporters, we studied NRRT50, as a cell toxicity marker, in enterocytes treated with PST and the ABCC transport inhibitor MK571. We incubated a suspension of isolated enterocytes $\left(10^{6}\right.$ viable cells $\mathrm{mL}^{-1}$, final

\section{a) Everted segment}
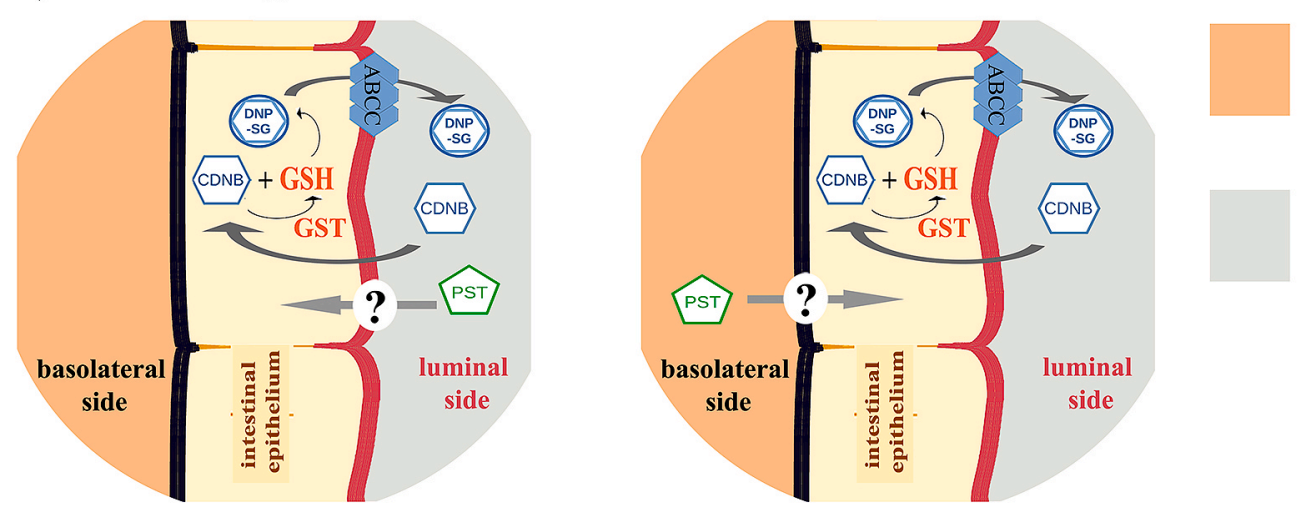

inside

the segment

\section{outside \\ the segment and detection of DNP-SG}

\section{b) Non-everted segment}
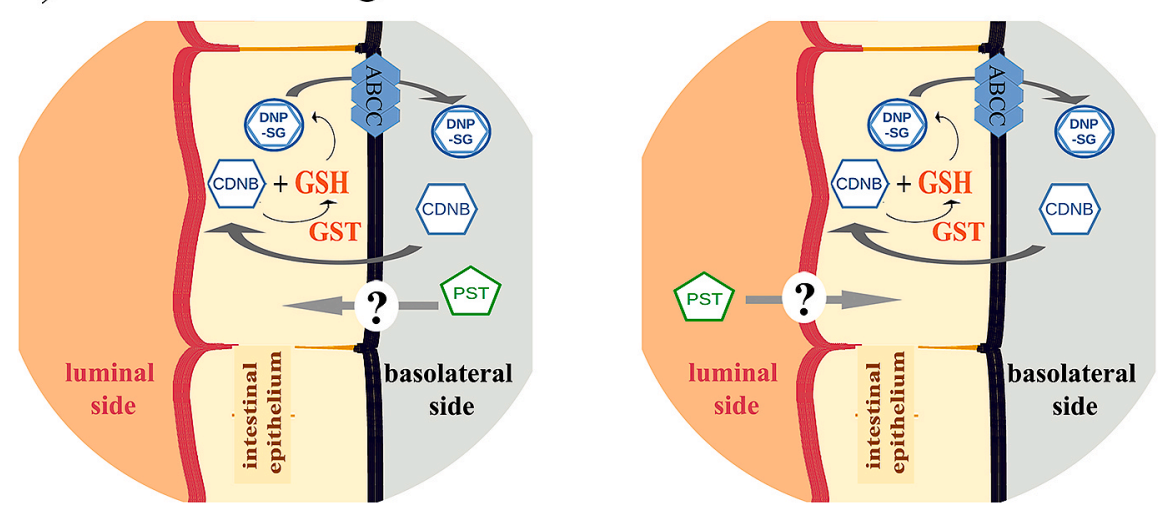

Fig. 1. Ex-vivo exposure design used to study polarized DNP-SG transport in Oncorhynchus mykiss middle intestine. Different preparations allowed the study of different possible routes of PST uptake and exportation by the cell a) Everted segments. b) Non-everted segments. In all the preparations DNP-SG concentration was measured in the bathing solution. 
concentration) for $1 \mathrm{~h}$ with $0.0033 \mu \mathrm{M}$ PST1, with or without $0.1 \mu \mathrm{M}$ MK571, dissolved in DMSO. This MK571 concentration was selected from a preliminary study of the concentration-dependent effects of this inhibitor on NRRT50 in isolated enterocytes (Fig. 6a) and on DNP-SG transport assays (Fig. 6b). In NRRT50 assays, we included a solvent control (DMSO). In both, NRRT50 and DNP-SG transport assays, the DMSO concentration was lower than $0.002 \%$.

\subsection{Statistics}

Bartlett's test was used to check homogeneity of variance and Kolmogorov-Smirnov test was used for checking normality. Differences among treatments were tested by paired Student's t-test, or repeated measures one-way ANOVA. We used Dunnett's pos hoc comparisons when the treatments were compared against the control, and Tukey's pos hoc comparisons for comparing among treatments. $P<0.05$ was considered as statistically significant (Zar, 1999). The arcsine square root transformation was applied before analyzing percentage data.

\section{Results}

\subsection{Intracellular effects}

\subsubsection{Glutathione and GSH-associated enzymes}

The intracellular glutathione metabolism was affected by $1 \mathrm{~h}$ of $e x$ vivo exposure to PST1 in the intestinal epithelium. The GSH content was diminished by $16.33 \%$ after exposure to $0.13 \mu \mathrm{M}$ PST1 and by $16.24 \%$, with 1.3 $\mu$ M PST1 (repeated measures, one-way ANOVA and Dunnett's pos hoc comparisons, $\mathrm{F}_{1.2,9.3}=1.50, p<0.05$ and $p<0.01$, respectively, $\mathrm{n}=9$ ) (Fig. 2a). GST activity decreased $19.3 \%$ after exposure to $0.13 \mu \mathrm{M}$ PST1 (repeated measures, one-way ANOVA and Dunnett's pos hoc comparisons, $\mathrm{F}_{1.9,} 11.6=4.639, p<0.05, \mathrm{n}=7$ ) but was not affected by $1.3 \mu \mathrm{M}$ PST1 (Fig. 2b). GR activity increased $14.27 \%$ with $0.13 \mu \mathrm{M}$ PST1 and $15.64 \%$ with $1.3 \mu \mathrm{M}$ PST1 but the effect was statistically significant only at the highest PST1 concentration (repeated measures, one-way ANOVA and Dunnett's pos hoc comparisons, $\mathrm{F}_{1.7}, 11.6=6.483, p<$ $0.05, \mathrm{n}=8$ ) (Fig. 2c).

\subsubsection{Oxidative stress biomarkers}

There were no significant effects of PST1 on the oxidative status of the middle intestine epithelium. Neither CAT activity nor lipid peroxidation in isolated epithelium were affected by PST1 (Fig. 3). ROS production in isolated enterocytes was not significantly augmented by 0.13 $\mu \mathrm{M}$ PST1, neither by PST1 plus $3 \mu \mathrm{M}$ MK571 (Fig. 3).

\subsubsection{Lysosomal membrane stability}

Lysosomal membrane stability was evaluated in order to find a sensitive marker for intracellular effects of PST. We registered a concentration-dependent effect of PST1, which fitted to a non-linear regression of NRRT50 (as percentage of the control) vs. log PST concentration $\left(\mathrm{IC}_{50}=0.0045 \mu \mathrm{M}\right.$ PST1; $95 \% \mathrm{CI}=0.0016$ to $0.0125 ; \mathrm{r}^{2}=$ $0.80 ; \mathrm{n}=6-7$ ) (Fig. 4).

\subsection{ABCC activity}

\subsubsection{DNP-SG transport}

All the tested PST extracts inhibited DNP-SG transport in isolated intestinal epithelium with respect to the control preparations (30.08, 50.66 and $32.26 \%$ for PST1, PST2 and PST3, respectively (repeated measures, one-way ANOVA and Dunnett's pos hoc comparisons, $\mathrm{F}_{2.2}, 13.1$ $=16.82, p<0.05, p<0.01$ and $p<0.05$, respectively, $\mathrm{n}=7$ ) (Fig. 5a).

According to these results, PST2 was selected for performing the assays with everted intestine segments. PST2 inhibited the basolateral DNP-SG transport by $17.62 \%$, but only when it was applied at the apical side (paired Student's t-test, $\mathrm{t}_{7}=3.99, p<0.01, \mathrm{n}=8$ ) (Fig. $5 \mathrm{~b}$ ). There was no effect of PST2 on apical DNP-SG transport.
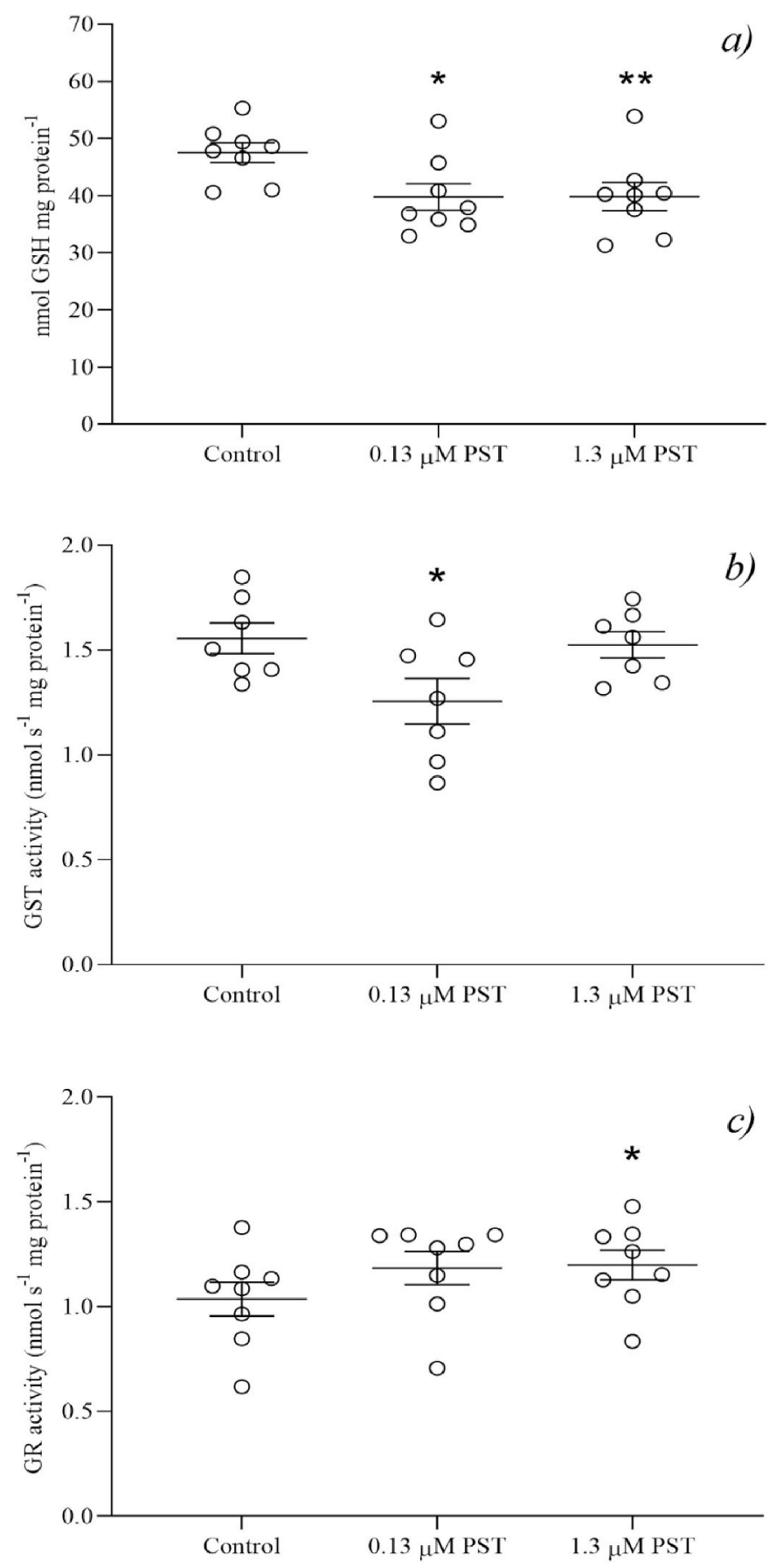

Fig. 2. Glutathione (GSH) content, and glutathione-S transferase (GST) and glutathione reductase (GR) activity in isolated Oncorhynchus mykiss middle intestine epithelium exposed ex vivo for $1 \mathrm{~h}$ to $0.13 \mu \mathrm{M}$ and $1.3 \mu \mathrm{M}$ PST1. Asterisks denote significant differences among treatments ( ${ }^{*} p<0.05 ;{ }^{*} p<0.01$ ). a) GSH content $(n=9)$. b) GST activity $(n=7)$. c) GR activity $(n=8)$.

\subsubsection{Effects of ABCC transport inhibition on PST cytotoxicity}

In a preliminary experiment with, isolated enterocytes, the exposure to $0.1-3 \mu \mathrm{M}$ of the ABCC transport inhibitor MK571, decreased NRRT50 in a concentration-dependent fashion (Fig. 6a). In addition, $0.1 \mu \mathrm{M}$ MK571 proved to be effective for inhibiting DNP-SG transport (one-way ANOVA and Dunnett's post hoc comparisons, $\mathrm{F}_{2,21}=4.74, p<0.05, \mathrm{n}=$ 6-9) (Fig. 6b). Consequently, we chose the lowest MK571 concentration $(0.1 \mu \mathrm{M})$ for the following assays, in order to avoid the effect of MK571 on NRRT50 as much as possible.

In the isolated enterocytes exposed to $0.1 \mu \mathrm{M}$ MK571, NRRT50 was 

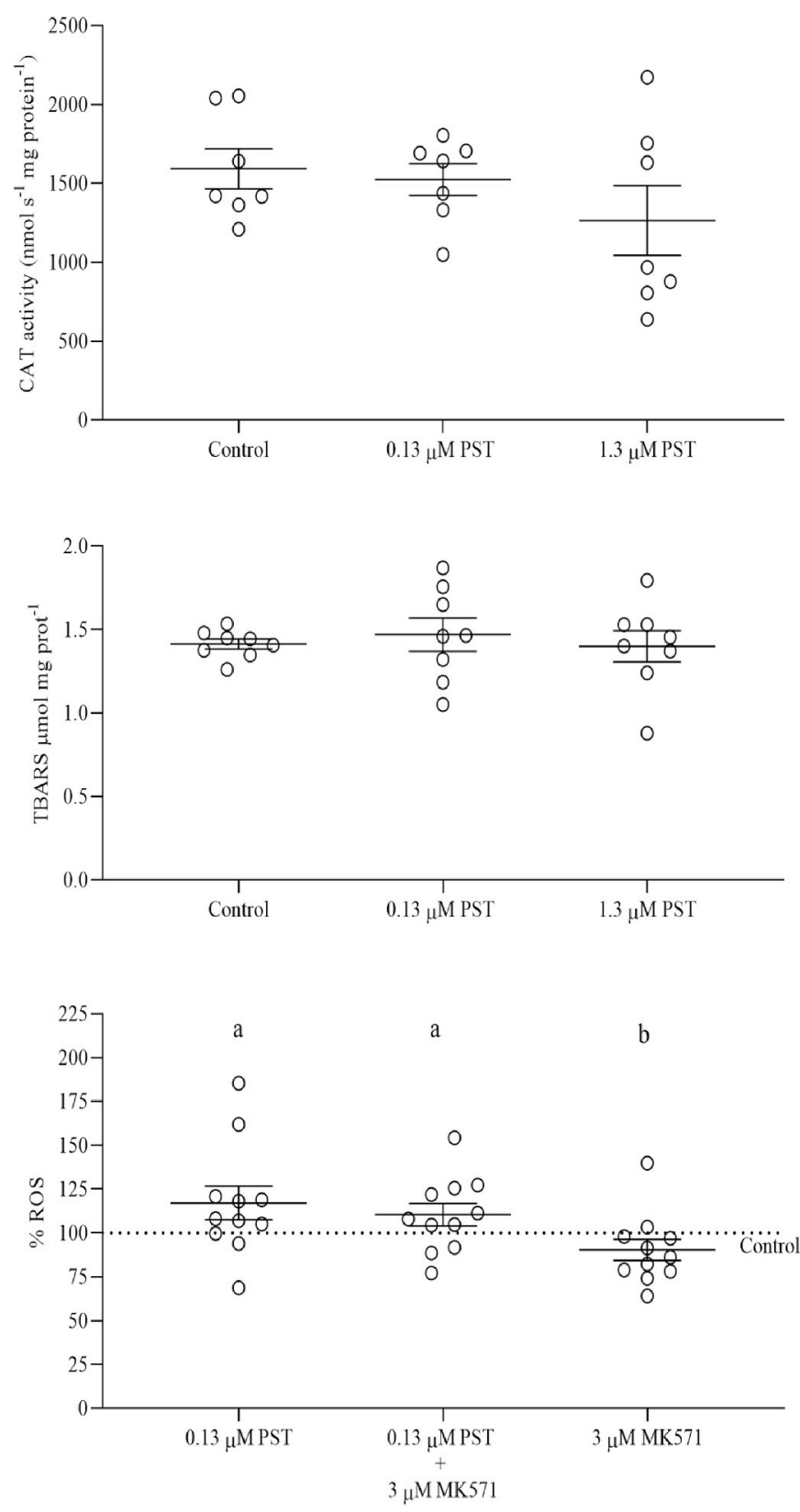

Fig. 3. Oxidative stress biomarkers in isolated Oncorhynchus mykiss middle intestine epithelium exposed ex vivo for $1 \mathrm{~h}$ to $0.13 \mu \mathrm{M}$ and $1.3 \mu \mathrm{MPST} 1$ (a, b) and to $0.13 \mu \mathrm{MPST} 1,0.13 \mu \mathrm{M}$ PST1 plus $3 \mu \mathrm{M}$ of the ABCC transport inhibitor MK571 and $3 \mu$ M MK571 (c). a) Catalase activity $(n=7)$; b) Lipid peroxidation (TBARS, $\mathrm{n}=8$ ); c) Reactive oxygen substances (ROS) level as $\%$ of the control $(\mathrm{n}=7)$; different letters indicate significant differences among treatments with $p<0.05$.

reduced by $18.17 \%$, with respect to the control, but this effect was not statistically significant. In turn, in the isolated enterocytes exposed to $0.0033 \mu \mathrm{M}$ PST1, NRRT50 was $51.40 \%$ lower than in control enterocytes (Tukey's pos hoc comparisons, $\mathrm{F}_{3,15}=27.99, p<0.0001, \mathrm{n}=6$ ). The coexposure to $0.0033 \mu \mathrm{M}$ PST1 plus $0.1 \mu \mathrm{M}$ MK571 reduced NRRT50 by $65.85 \%$, with respect to the control (Tukey's pos hoc comparisons, $\mathrm{F}_{3,15}$ $=27.99, p<0.0001, \mathrm{n}=6$ ). There were not significant differences between the effects of PST1 alone and PST1 plus $0.1 \mu \mathrm{M}$ MK571 (Fig. 6c).

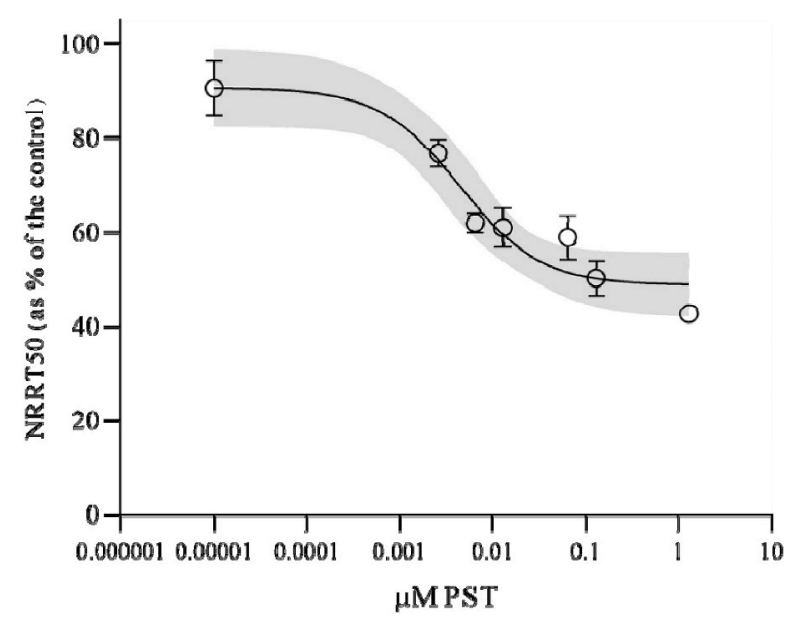

Fig. 4. Lysosomal damage in isolated Oncorhynchus mykiss enterocytes exposed in vitro for $1 \mathrm{~h}$ to PST1. Non-linear regression curve for log PST1 concentration $(\mu \mathrm{M})$ vs. neutral red retention time 50\% (NRRT50) (min) expressed as percentage of the control. Values are mean \pm SEM $(n=6-7), \mathrm{IC}_{50}=0.0045 \mu \mathrm{M}$ PST1, 95\% CI $=0.0016$ to 0.0125 (grey area), $\mathrm{r}^{2}=0.80$.
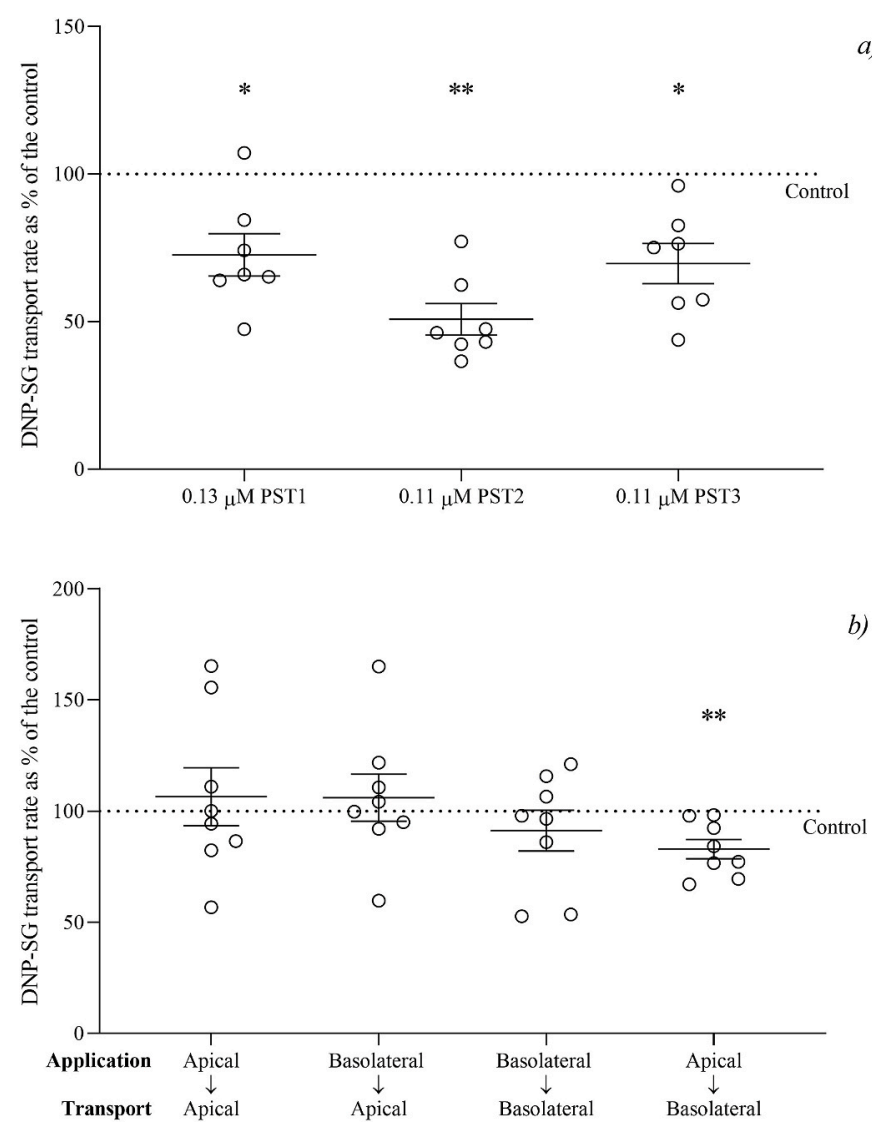

Fig. 5. DNP-SG transport rate as percentage of the control in Oncorhynchus mykiss middle intestine preparations. a) Isolated epithelium $(\mathrm{n}=7)$. b) Everted and non-everted segments $(n=8)$. The statistical analysis was run with raw data. Asterisks denote significant differences with respect the the control (* $p<$ $0.05 ; * * p<0.01$ ).

\section{Discussion}

This study provides evidence on the absorption of PST by the middle intestine epithelium of $O$. mykiss obtained in ex vivo and in vitro experiments. The obtained results show, for the first time, that these toxins are 

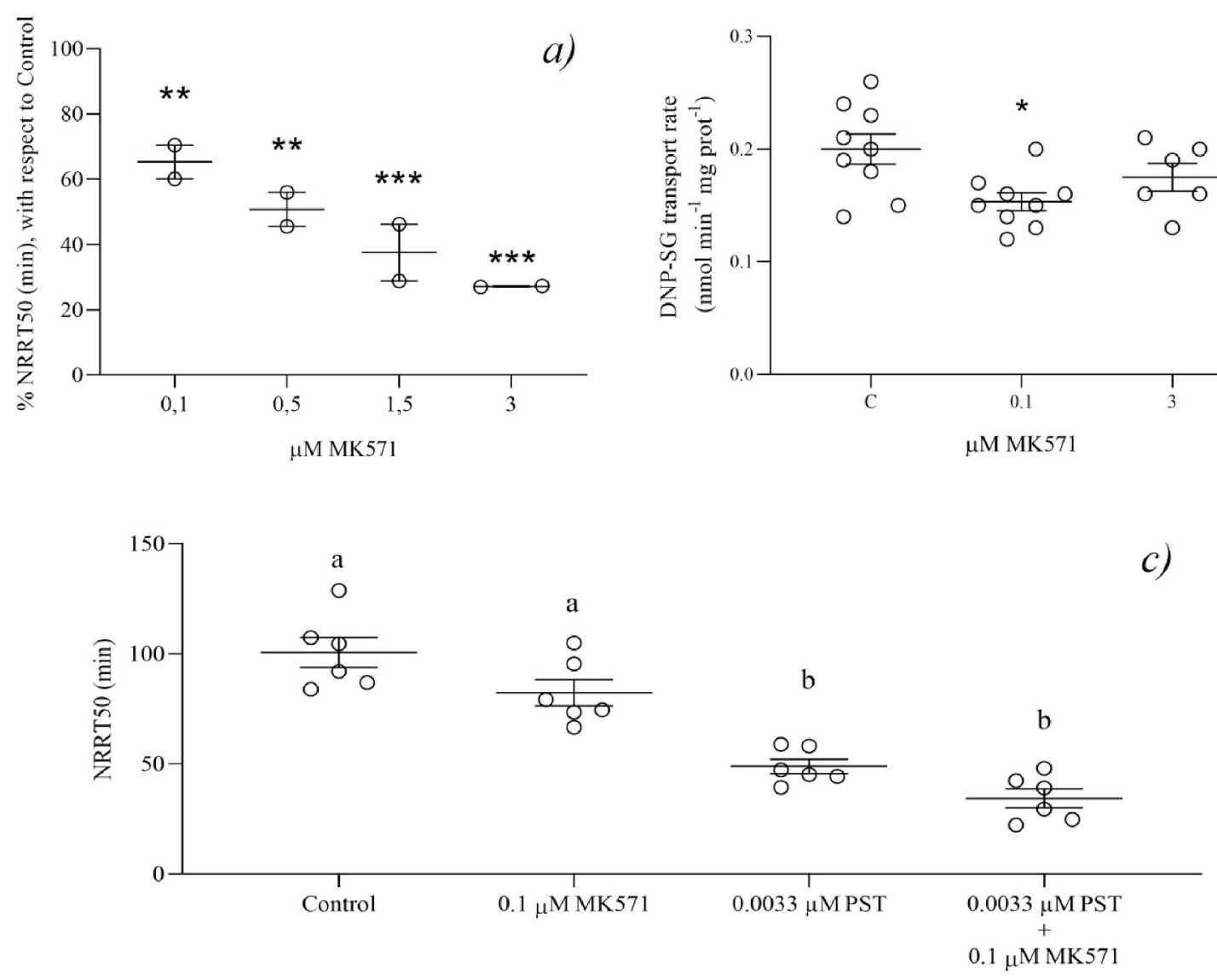

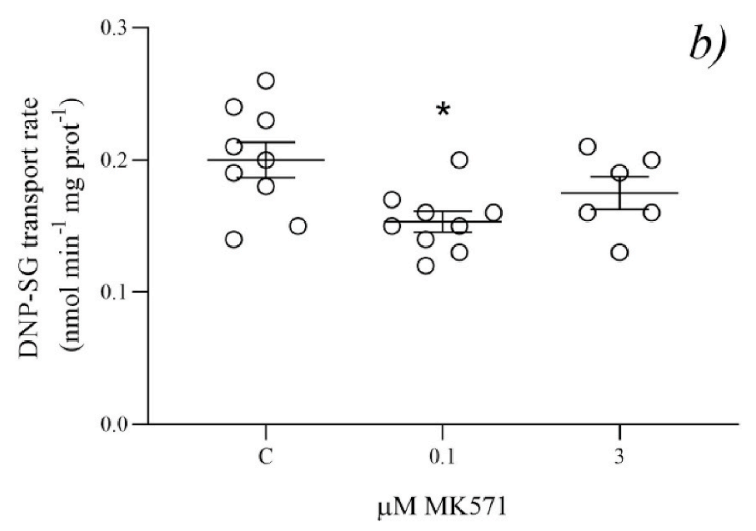

c)

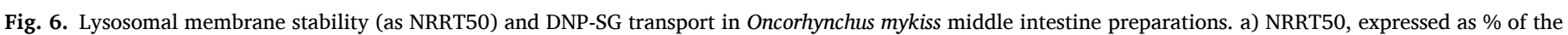

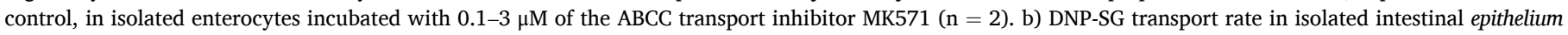

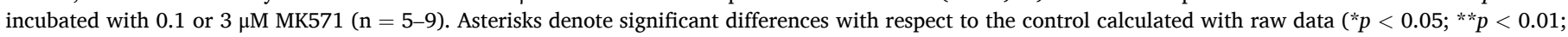

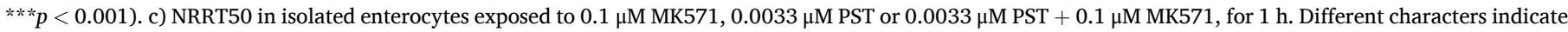
significant differences among groups $(p<0.01, \mathrm{n}=6)$.

taken up by the cells of fish intestine epithelium, affect glutathione metabolism and produce cytotoxic effects even after a short exposure (1 h) to PST concentrations below the recommended values for drinking water. We also show for, the first time, that PST interfere with the MXR defense system by inhibiting ABCC-mediated transport.

Several works report that in mammals, including humans, PST are absorbed in the intestine through paracellular transport (Andrinolo et al., 2002a, 2002b; Torres et al., 2007) and that their elimination takes place mostly in the kidney by glomerular filtration. However, reports on the presence of PST in bile (García et al., 2004, 2010; Gessner et al., 1997) and the report of STX being transported through ABCB1 (Pgp) in a mouse hippocampal cell line (Ramos et al., 2018) suggest that PST can be transported transcellularly by active transporters such as $\mathrm{ABC}$ proteins.

In contrast, PST intestinal absorption in fish has received little attention. Gao et al. (2019) reported that the seawater pufferfish Takifugu pardalis fed with tetrodotoxin (TTX) and STX rapidly accumulates TTX in specific tissues while most STX remains in the intestine. The opposite occurs with the freshwater pufferfish Pao suvattii, which accumulates STX in skin, ovary and intestine but keeps little or no TTX in the body (Gao et al., 2019). These studies do not analyze the mechanisms by which a specific toxin can cross the intestinal wall, while the other cannot, but suggest the selectivity of fish intestine for different toxins. However, as far as we know, there are no reports on the transcellular uptake of PST in vertebrates' intestine, neither on intracellular effects of PST in this organ.

GSH depletion is generally regarded as indicative of pro-oxidant conditions since GSH is oxidized to GSSG in the presence of ROS
(Deponte, 2013; Meister and Anderson, 1983; Wu et al., 2004). We have found that $0.13 \mu \mathrm{M}$ PST1 causes a mild but significant decrease of intracellular GSH content, but the effect is not increased at a higher PST1 concentration (1.3 $\mu \mathrm{M}$ PST1). Accordingly, the increase in GR activity at the highest PST1 concentration could explain the lack of concentration dependence in GSH content through augmented recycling of GSSG to GSH. The fact that the increase in GR activity seems to stabilize the GSH content but does not reverse the depletion suggests that GSH is being consumed or oxidized in some biotransformation reaction. In this sense, the conversion between PST analogues, such as GTXs into SXTs, with the formation of thiol-conjugated intermediates, has been demonstrated by Sato et al. (2000) and Sakamoto et al. (2000) for bacteria and in laboratory reactions. In bivalves, $\mathrm{N}$-sulfocarbamoyl toxins (C1 and $\mathrm{C} 2)$ are reduced to carbamoyl toxins (GTX1-GTX4, NEO and STX) (Cembella et al., 1994; Asakawa et al., 1987). In fish, this kind of biotransformation has been suggested in the Atlantic salmon (Salmo salar) and in the white seabream (Diplodus sargus), respectively Gubbins et al. (2000) and Costa et al. (2011). Considering that PST1 contains 39\% GTX1/4 and 35\% of $\mathrm{C} 1 / 2$, the decrease in GSH content observed in our experiment could reflect the occurrence of biotransformation reactions that involve GSH conjugation and/or oxidation in $O$. mykiss enterocytes. Another alternative explanation for the observed decrease in GSH content of enterocytes could be the exportation of GSH from the cells as a co-substrate for the transport of toxins through ABCC proteins.

The participation of GST in the detoxification of PST is still unclear. In fish, GST activity has been reported to increase after exposure to PST (Calado et al., 2020; Clemente et al., 2010; Gubbins et al., 2000), or to decrease (Silva et al., 2011; Barbosa et al., 2019 ), while in mice and in 
cladoceran crustaceans, PST have no effect on GST activity (Ferrão-Filho et al., 2017; Hong et al., 2003). An increase in GST activity can be related with increased antioxidant and/or biotransformation activity (Calado et al., 2020; Stephensen et al., 2002; Painefilú et al., 2019). In the present work, we observe a decrease in GST activity with $0.13 \mu \mathrm{M}$ PST1, which could be related to GSH depletion; however, this effect is not evident at higher PST1 concentration $(1.3 \mu \mathrm{M})$. At this concentration, GR activity is significantly increased and could provide GSH by reducing GSSG to maintain GST activity, at least in the short term (Li et al., 2011; Vieira et al., 2009). However, we could not measure GSSG content to further support this idea.

All the PST extracts studied in this work inhibited the DNP-SG transport. According to their composition (see Table 1), PST2 and PST3 should be 6-fold less neurotoxic than PST1. On the other hand, PST2 resulted the most potent transport inhibitor (50\% at $0.11 \mu \mathrm{M})$. In the experiments with polarized preparations, PST2 was able to inhibit basolateral but not apical DNP-SG transport, which differs from previous reports by our group, in which microcystin-LR and arsenite have inhibited DNP-SG transport at both sides of $O$. mykiss intestinal epithelium (Bieczynski et al., 2014; Painefilú et al., 2019). In addition, PST2 inhibited basolateral transport only when it was applied to the apical side. This suggests that at least one of the toxins contained in PST2 can cross the apical membrane of the enterocytes and inhibit DNP-SG transport through basolateral ABCC proteins either as competitive (substrate) or noncompetitive inhibitor. This also suggests that PST do not enter the enterocytes from the blood.

Garcia et al. (2010, 2009) have proposed that PST can be detoxified by oxidation followed by glucuronidation, which is considered an important process for detoxification of xenobiotics in rainbow trout (Clarke et al., 1991, for a review; Lahti et al., 2011). Besides, glucuronide conjugates have been described as substrates for basolateral $\mathrm{ABC}$ transporters, such as ABCC3 and ABCC4 (Bai et al., 2004; Deeley et al., 2006, for a review; Zamek-Gliszczynski et al., 2006, for a review). Unlike the apical ABCC2, human basolateral ABCCs, especially ABCC3 have more affinity for glucuronide conjugates than for GSH conjugates such as DNP-SG (Zamek-Gliszczynski et al., 2006). Thus, the possible transport of glucuronide-conjugated PST through ABCC3 and/or ABCC4 in $O$. mykiss deserves further analysis.

In order to gather more evidence about the possible transport of PST or their metabolites through basolateral ABCC proteins, we have studied the effects of PST1 alone or combined with the ABCC inhibitor MK571. PST1 significantly reduces NRRT50, but blocking ABCCs with MK571 does not increase this effect, as it would be expected, if PST were transported through ABCCs (Bieczynski et al., 2014, 2016). Thus, PST components would more likely inhibit basolateral ABCC-mediated transport by a non-competitive mechanism.

The strong concentration-dependent effect of PST1 on lysosomal neutral red retention $\left(\mathrm{IC}_{50}=0.0045 \mu \mathrm{M}\left(1.34 \mu \mathrm{g}\right.\right.$ STXeq $\left.\left.\mathrm{L}^{-1}\right)\right)$ shows that these toxins are absorbed into $O$. mykiss enterocytes and are cytotoxic at concentrations that are lower than the guideline values for drinking water (3 $\mu \mathrm{g}$ STXeq $\mathrm{L}^{-1}$ for children, and $20 \mu \mathrm{g}$ STXeq $\mathrm{L}^{-1}$ for adults, WHO, 2019). Besides the considerations for human health, this finding suggests that PST producing blooms could affect the digestive system of fish, particularly in aquaculture facilities, at non-neurotoxic concentrations (FAO, 2016; Testai et al., 2016b). The observed cytotoxic effects could be explained by toxin binding to voltage-gated $\mathrm{Na}^{+}$and/or $\mathrm{Ca}^{+}$ channels in the lysosomal membrane, which are critical for lysosomal functions (Xu and Ren, 2016). This also suggests NRRT50 in O. mykiss enterocytes as a sensitive end-point for PST toxicology.

\section{Conclusions}

In O. mykiss, PST present in the intestinal lumen are absorbed into the epithelial cells and produce cytotoxic effects, even at low concentrations. This means that the digestive physiology of fish can be altered when are exposed to blooms or surface scums of PST producing microorganisms, e.g. in aquaculture facilities. These alterations can produce adverse consequences in fish health and growth, in the absence of visible neurotoxic effects. In addition, the fact that PST inhibit the basolateral ABCC transporters suggests that these toxins can enhance the toxicity of other toxins by delaying their transport out of the intestinal cells. Particularly, microcystin-LR can be produced together with PST by freshwater cyanobacteria and are exported from fish intestinal cells through ABCC proteins.

We can conclude that PST are not eliminated from $O$. mykiss intestinal cells by $A B C C$ transporters but affect their function. Thus, the participation of other xenobiotic transporters, which are expressed in the intestine and in other organs of fish, such as ABCB1 and ATP-binding cassette class $\mathrm{G}$ protein 2 (ABCG2), together with biotransformation enzymes, should be investigated in order to understand PST detoxification and transport in fish.

\section{Ethics approval}

The experimental protocols were approved by the Bioethics Committee, Faculty of Biochemical and Pharmaceutical Sciences, National University of Rosario, Argentina (6060/116).

\section{Credit author statement}

Julio C. Painefilu: Conceptualization, Methodology, Investigation, Visualization, Formal analysis, Writing- Original Draft. Virginia A. Bianchi: Investigation. Bernd Krock: Methodology, Writing-Review \& Editing. Julieta S. De Anna: Investigation. Gisela Kristoff, WritingReviewing and Editing. Carlos M. Luquet: Conceptualization, Resources, Supervision, Writing- Reviewing and Editing.

\section{Declaration of competing interest}

The authors declare that they have no conflict of interest.

\section{Acknowledgments}

This work was supported by grants CONICET PIP 11220130100529CO; and ANPCYT-PICT 2013-1415 and 2018-02653 to CML. We would like to thank the Centro de Ecología Acuática del Neuquén staff, particularly to Pablo Hualde, Pablo Morzenti and Water Torres for their kind help with fish and aquaria.

\section{References}

Aebi, H., 1984. Catalase in vitro. Methods Enzymol. 105, 121-126.

Amado, L.L., Garcia, M.L., Ramos, P.B., Freitas, R.F., Zafalon, B., Ferreira, J.L.R., Yunes, J.S., Monserrat, J.M., 2009. A method to measure total antioxidant capacity against peroxyl radicals in aquatic organisms: application to evaluate microcystins toxicity. Sci. Total Environ. 407, 2115-2123. https://doi.org/10.1016/j. scitotenv.2008.11.038.

Andrinolo, D., Gomes, P., Fraga, S., Soares-da-Silva, P., Lagos, N., 2002a. Transport of the organic cations gonyautoxin $2 / 3$ epimers, a paralytic shellfish poison toxin, through the human and rat intestinal epitheliums. Toxicon 40, 1389-1397.

Andrinolo, D., Iglesias, V., García, C., Lagos, N., 2002b. Toxicokinetics and toxicodynamics of gonyautoxins after an oral toxin dose in cats. Toxicon 40, 699-709.

Asakawa, M., Takagi, M., Iida, A., Oishi, K., 1987. Studies on the conversion of Paralytic Shellfish Poison (PSP) components by biochemical reducing agents. Eisei Kagaku 33, 50-55.

Bai, J., Lai, L., Ching, H., Cher, B., Tan, T.M.C., 2004. Multidrug resistance protein 4 (MRP4/ABCC4) mediates efflux of bimane-glutathione. Int. J. Biochem. Cell Biol. 36, 247-257. https://doi.org/10.1016/S1357-2725(03)00236-X.

Bakke, J.M., Horsberg, T.E., 2007. Effects of algal-produced neurotoxins on metabolic activityin telencephalon, optic tectum and cerebellum of Atlantic salmon (Salmo salar). Aquat. Toxicol. 85, 96-103. https://doi.org/10.1016/j.aquatox.2007.08.003.

Bakke, J.M., Horsberg, T.E., 2010. Kinetic properties of saxitoxin in Atlantic salmon (Salmo salar) and Atlantic cod (Gadusmorhua). Comp. Biochem. Physiol., C 152, 444-450. https://doi.org/10.1016/j.cbpc.2010.07.005.

Bakke, M.J., Hustoft, H.K., Horsberg, T.E., 2010. Subclinical effects of saxitoxin and domoic acid on aggressive behaviour and monoaminergic turnover in rainbow trout 
(Oncorhynchus mykiss). Aquat. Toxicol. 99, 1-9. https://doi.org/10.1016/j. aquatox.2010.03.013.

Barbosa, B., Santos, M., Anacleto, P., Maulvault, A.L., Pousão-Ferreira, P., Costa, P.C., Marques, A., 2019. Paralytic shellfish toxins and ocean warming: bioaccumulation and ecotoxicological responses in juvenile gilthead seabream (Sparus aurata). Toxins 11, 408. https://doi.org/10.3390/toxins11070408.

Bard, S.M., 2000. Multixenobiotic resistance as a cellular defense mechanism in aquatic organisms. Aquat. Toxicol. 48, 357-389. https://doi.org/10.1016/S0166-445X(00) 00088-6.

Bieczynski, F., Anna, J.S. De, Pirez, M., Brena, B.M., Villanueva, S.S.M., Luquet, C.M., 2014. Cellular transport of microcystin-LR in rainbow trout (Oncorhynchus mykiss) across the intestinal wall: possible involvement of multidrug resistance-associated proteins. Aquat. Toxicol. 154, 97-106. https://doi.org/10.1016/j. aquatox.2014.05.003.

Bieczynski, F., Torres, W.D.C., Painefilú, J.C., Castro, J.M., Bianchi, V.A., Frontera, J.L., Paz, D.A., González, C., Martín, A., Villanueva, S.S.M., Luquet, C.M., 2016. Alterations in the intestine of Patagonian silverside (Odontesthes hatcheri) exposed to microcystin-LR: changes in the glycosylation pattern of the intestinal wall and inhibition of multidrug resistance proteins efflux activity. Aquat. Toxicol. 178, 106-117. https://doi.org/10.1016/j.aquatox.2016.07.016.

Bricelj, V.M., Shumway, S.E., 1998. Paralytic shellfish toxins in bivalve molluscs: occurrence, transfer kinetics, and biotransformation. Rev. Fish. Sci. 6 (4), 315-383.

Calado, S.L. de M., Santos, G.S., Vicentini, M., Bozza, D.C., Prodocimo, V., Magalhães, V. F. de, Cestari, M.M., Silva de Assis, H.C., 2020. Multiple biomarkers response in a Neotropical fish exposed to paralytic shellfish toxins (PSTs). Chemosphere. https:// doi.org/10.1016/j.chemosphere.2019.124616.

Catterall, W.A., 1980. Neurotoxins that act on voltage-sensitive sodium channels in excitable membranes. Annu. Rev. Pharmacol. Toxicol. 20, 15-43. https://doi.org/ 10.1146/annurev.pa.20.040180.000311.

Cembella, A., Quilliam, M., Lewis, N., Bauder, A., Dell'Aversano, C., Thomas, K., Jellett, J., Cusack, R., 2002. The toxigenic marine dinoflagellate Alexandrium tamarense as the probable cause of mortality of caged salmon in Nova Scotia. Harmful Algae 1, 313-325. https://doi.org/10.1016/S1568-9883(02)00048-3.

Cembella, A.D., Shumway, S.E., Larocque, R., 1994. Sequestering and putative biotransformation of paralytic seasonal and spatial scales in natural populations. J. Exp. Mar. Biol. Ecol. 180, 1-22.

Clarke, D.J., George, S.G., Burchell, B., 1991. Glucuronidation in fish. Aquat. Toxicol. 20, $35-56$.

Clemente, Z., Busato, R.H., Oliveira, C.A., Cestari, M.M., Magalha, F., Wosiack, A.C., Silva, H.C., Assis, D., Ramsdorf, W.A., 2010. Toxicon Analyses of Paralytic Shellfish Toxins and Biomarkers in a Southern Brazilian Reservoir, vol. 55, pp. 396-406. https://doi.org/10.1016/j.toxicon.2009.09.003.

Costa, P.R., Lage, S., Barata, M., Pousao-Ferreira, P., 2011. Uptake, transformation, and elimination kinetics of paralytic shellfish toxins in white seabream (Diplodus sargus). Mar. Biol. 158, 2805-2811. https://doi.org/10.1007/s00227-011-1779-3.

Costa, P.R., Pereira, P., Guilherme, S., Barata, M., Nicolau, L., Santos, M.A., Pacheco, M., Pousão-Ferreira, P., 2012. Biotransformation modulation and genotoxicity in white seabream upon exposure to paralytic shellfish toxins produced by Gymnodinium catenatum. Aquat. Toxicol. 106-107, 42-47. https://doi.org/10.1016/j. aquatox.2011.08.023.

Dayeh, V.R., Bols, N.C., Schirmer, K., Lee, L.E.J., 2003. The use of fish-derived cell lines for investigation of environmental contaminants. Curr. Protoc. Toxicol. 15, 1-7. https://doi.org/10.1002/0471140856.tx0105s15.

Deeds, J.R., Landsberg, J.H., Etheridge, S.M., Pitcher, G.C., 2008. Non-traditional Vectors for Paralytic Shellfish Poisoning, pp. 308-348. https://doi.org/10.3390/ md20080015.

Deeley, R.G., Westlake, C., Cole, S.P.C., 2006. Transmembrane transport of endo- and xenobiotics by mammalian ATP-binding cassette multidrug resistance proteins. Physiol. Rev. 86, 849-899. https://doi.org/10.1152/physrev.00035.2005.

Deponte, M., 2013. Glutathione catalysis and the reaction mechanisms of glutathionedependent enzymes. Biochim. Biophys. Acta 1830, 3217-3266. https://doi.org/ 10.1016/j.bbagen.2012.09.018.

Ellman, G.L., 1959. Tissue sulfhydryl groups. Arch. Biochem. Biophys. 82, 70-77.

Epel, D., Luckenbach, T., Stevenson, C.N., MacManus-Spencer, L.A., Hamdoun, A., Smital, T., 2008. Efflux transporters: newly appreciated roles in protection against pollutants. Environ. Sci. Technol. 42, 3914-3920. https://doi.org/10.1021/ es087187v.

Etheridge, S.M., 2010. Paralytic shellfish poisoning: seafood safety and human health perspectives. Toxicon 56, 108-122. https://doi.org/10.1016/j.toxicon.2009.12.013.

FAO/WHO, 2016. Technical paper on toxicity equivalency factors for marine biotoxins associated with bivalve molluscs.

Ferrão-Filho, A.S, Abreu, S.S.D., Oliveira, T.A., Magalhães, V.F., Pflugmacher, S., Silva, S. M, 2017. Single and combined effects of microcystin- and saxitoxin- producing cyanobacteria on the fitness and antioxidant defenses of cladocerans. Environ. Toxicol. Chem. 36, 2689-2697. https://doi.org/10.1002/etc.3819.

Ferrão-Filho, A.S., Kozlowsky-Suzuki, B., 2011. Cyanotoxins: bioaccumulation and effects on aquatic animals. Mar. Drugs 9, 2729-2772. https://doi.org/10.3390/ md9122729.

Fraga, C.G., Leibovitz, B.E., Tappel, A.L., 1988. Lipid peroxidation measured as thiobarbituric acid-reative substances in tissue slices: characterization and comparison with homogenates and microsomes. Free Radic. Biol. Med. 4, 155-161. https://doi.org/10.1016/0891-5849(88)90023-8.

Galvão, J.A., Oetterer, M., Bittencourt-Oliveira, M.C., Gouvêa-Barros, S., Hiller, S. Erler, K., Luckas, B., Pinto, E., Kujbida, P., 2009. Saxitoxins accumulation by freshwater tilapia (Oreochromis niloticus) for human consumption. Toxicon 54, 891-894. https://doi.org/10.1016/j.toxicon.2009.06.021.
Gao, W., Kanahara, Y., Yamada, M., Tatsuno, R., Yoshikawa, H., Doi, H., Takatani, T., Arakawa, O., 2019. Contrasting toxin selectivity between the marine pufferfish Takifugu pardalis and the freshwater pufferfish Pao suvattii. Toxins 11 (470), 1-11. https://doi.org/10.3390/toxins11080470.

García, C., Barriga, A., Díaz, J.C., Lagos, M., Lagos, N., 2010. Route of metabolization and detoxication of paralytic shellfish toxins in humans. Toxicon 55, 135-144. https://doi.org/10.1016/j.toxicon.2009.07.018.

García, C., Bravo, M., del, C., Lagos, M., Lagos, N., 2004. Paralytic shellfish poisoning: post-mortem analysis of tissue and body fluid samples from human victims in the Patagonia fjords. Toxicon 43, 149-158. https://doi.org/10.1016/j. toxicon.2003.11.018.

García, C., Rodriguez-Navarro, A., Díaz, J.C., Torres, R., Lagos, N., 2009. Evidence of in vitro glucuronidation and enzymatic transformation of paralytic shellfish toxins by healthy human liver microsomes fraction. Toxicon 53, 206-213. https://doi.org/ 10.1016/j.toxicon.2008.10.028.

Gessner, B.D., Bell, P., Doucette, G.J., Moczydlowski, E., Poli, M.A., Van Dolah, F., Hall, S., 1997. Hypertension and identification of toxin in human urine and serum following a cluster of mussel-associated paralytic shellfish poisoning outbreaks. Toxicon 35, 711-722. https://doi.org/10.1016/S0041-0101(96)00154-7.

Grolleau, F., Gamelin, L., Boisdron-Celle, M., Lapied, B., Pelhate, M., Gamelin, E., 2001. A possible explanation for a neurotoxic effect of the anticancer agent oxaliplatin on neuronal voltage-gated sodium channels. J. Neurophysiol. 85, 2293-2297. https:// doi.org/10.1152/jn.2001.85.5.2293.

Gubbins, M.J., Eddy, F.B., Gallacher, S., Stagg, R.M., 2000. Paralytic shellfish poisoning toxins induce xenobiotic metabolising enzymes in Atlantic salmon (Salmo salar). Mar. Environ. Res. 50, 479-483.

Habig, W.H., Pabst, M.J., Jakoby, W.B., 1974. Glutathione S-Transferases: the first enzymatic step in mercapturic acid formation. J. Biol. Chem. 249, 7130-7140.

Hong, H., Lam, P.K.S., Hsieh, D.H.S., 2003. Interactions of paralytic shellfish toxins with xenobiotic-metabolizing and antioxidant enzymes in rodents. Toxicon 42 (4), 425-431. https://doi.org/10.1016/S0041-0101(03)00175-2.

Kellmann, R., Ploux, O., Neilan, B.A., 2013. Neurotoxic alkaloids from cyanobacteria. In: Ramawat, K.G., Merillon, J.-M. (Eds.), Natural Products: Phytochemistry, Botany and Metabolism of Alkaloids, Phenolics and Terpenes. Springer Berlin Heidelberg, p. 4285. https://doi.org/10.1007/978-3-642-22144-6.

Kurelec, B., 1992. The multixenobiotic resistance mechanism in aquatic organisms. Crit. Rev. Toxicol. 22, 23-43. https://doi.org/10.3109/10408449209145320.

Kwong, R.W.M., Niyogi, S., 2012. Cadmium transport in isolated enterocytes of freshwater rainbow trout: interactions with zinc and iron, effects of complexation with cysteine, and an ATPase-coupled efflux. Comp. Biochem. Physiol., C 155, 238-246. https://doi.org/10.1016/j.cbpc.2011.09.001.

Lagos, N., 2003. Paralytic shellfish poisoning phycotoxins: occurrence in South America. Comments Toxicol. 9, 175-193. https://doi.org/10.1080/08865140390215053.

Lahti, M., Brozinski, J.-M., Jylha, A., Kronberg, L., Oikari, A., 2011. Uptake from water, biotransformation, and biliary excretion of pharmaceuticals by rainbow trout. Environ. Toxicol. Chem. 30, 1403-1411. https://doi.org/10.1002/etc.501.

Lefebvre, K.A., Trainer, V.L., Scholz, N.L., 2004. Morphological abnormalities and sensorimotor deficits in larval fish exposed to dissolved saxitoxin. Aquat. Toxicol. 66, 159-170. https://doi.org/10.1016/j.aquatox.2003.08.006.

Li, Z., Li, P., Randak, T., 2011. Evaluating the toxicity of environmental concentrations of waterborne chromium (VI) to a model teleost, Oncorhynchus mykiss: a comparative study of in vivo and in vitro. Comp. Biochem. Physiol., C 153, 402-407. https://doi. org/10.1016/j.cbpc.2011.01.005.

Lopes, V.M., Baptista, M., Repolho, T., Rosa, R., Reis, P., 2014. Uptake, transfer and elimination kinetics of paralytic shellfish toxins in common octopus (Octopus vulgaris). Aquat. Toxicol. 146, 205-211. https://doi.org/10.1016/j. aquatox.2013.11.011.

Lowry, O.H., Rosebrough, N.J., Farr, A.L., Randall, R.J., 1951. Protein measurement with the Folin phenol reagent. J. Biol. Chem. 193, 265-275.

Lukowski, A.L., Denomme, N., Hinze, M.E., Hall, S., Isom, L.L., Narayan, A.R.H., 2019. Biocatalytic detoxification of paralytic shellfish toxins. ACS Chem. Biol. 14, 941-948. https://doi.org/10.1021/acschembio.9b00123.

Madigan, T., Malhi, N., Tan, J., Mcleod, C., Stewart, I., Harwood, T., Mann, G., Turnbull, A., 2018. Experimental uptake and depuration of paralytic shellfish toxins in Southern Rock Lobster, Jasusedwardsii. Toxicon 143, 44-50. https://doi.org/ 10.1016/j.toxicon.2018.01.001.

Mamaca, E., Bechmann, R.K., Torgrimsen, S., Aas, E., Bjørnstad, A., Baussant, T., Floch, S. Le, 2005. The neutral red lysosomal retention assay and Comet assay on haemolymph cells from mussels (Mytilus edulis) and fish (Symphodus melops) exposed to styrene. Aquat. Toxicol. 75, 191-201. https://doi.org/10.1016/j. aquatox.2005.08.001.

Meister, A., Anderson, M.E., 1983. Glutathione. Annu. Rev. Biochem. 52, 711-760.

Montoya, N.G., Akselman, R., Pajaro, M., Perrota, R.G., Carreto, J.I., 1997. Presencia de veneno paralizante de moluscos en higado de caballa de la región costera bonaerense. Rev. Invest. Desarro. Pesq. 11, 145-152.

Moss, B., Bassem, A., 2006. Fluorometric measurement of oxidative burst in lobster hemocytes and inhibiting effect of pathogenic bacteria and hypoxia. J. Shellfish Res. 25 (3), 1051-1057. https://doi.org/10.2983/0730-8000(2006)25[1051:FMOOBI] 2.0.CO;2.

Myint, K., Biswas, R., Li, Y., Jong, N., Jamieson, S., Liu, J., Han, C., Squire, C., Merien, F., Lu, J., Nakanishi, T., Tamai, I., Mckeage, M., 2019. Identification of MRP2 as a targetable factor limiting oxaliplatin accumulation and response in gastrointestinal cancer. Sci. Rep. 1-12. https://doi.org/10.1038/s41598-019-38667-8.

Omiecinski, C.J., Vanden Heuvel, J.P., Perdew, G.H., Peters, J.M., 2011. Xenobiotic metabolism, disposition, and regulation by receptors: from biochemical 
phenomenon to predictors of major toxicities. Toxicol. Sci. 120, 49-75. https://doi. org/10.1093/toxsci/kfq338.

Painefilú, J.C., Pascual, M.M., Bieczynski, F., Laspoumaderes, C., González, C., Villanueva, S.S.M., Luquet, C.M., 2019. Ex vivo and in vivo effects of arsenite on GST and ABCC2 activity and expression in the middle intestine of the rainbow trout Oncorhynchus mykiss. Comp. Biochem. Physiol. C Toxicol. Pharmacol. 225 https:// doi.org/10.1016/j.cbpc.2019.108566.

Parkinson, A., Ogilvie, B.W., 2008. Biotransformation of xenobiotics. In: Klaassen, C.D. (Ed.), Toxicology: the Basic Science of Poisons. McGraw-Hill, New York, p. 1331. https://doi.org/10.1036/0071470514.

Ramos, P., Schmitz, M., Gama, S., Portantiolo, A., Durruthy, M.G., de Souza Votto, A.P., Cornetet, L.R., dos Santos Machado, K., Wehrli, A., Tonel, M.Z., Binotto Fagan, S., Monserrat, J.M., 2018. Cytoprotection of lipoic acid against toxicity induced by saxitoxin in hippocampal cell line HT-22 through in silico modeling and in vitro assays. Toxicology 393, 171-184. https://doi.org/10.1016/j.tox.2017.11.004.

Sakamoto, S., Sato, S., Ogata, T., Kodama, M., 2000. Formation of intermediate conjugates in the reductive transformation of gonyautoxins to saxitoxins by thiol compounds. Fish. Sci. 66, 136-141.

Sato, S., Sakai, R., Kodama, M., 2000. Identification of Thioether Intermediates in the Reductive Transformation of Gonyautoxins into Saxitoxins by Thiols, vol. 10, pp. 1787-1789.

Schaedle, M., Bassham, J.A., 1977. Chloroplast glutathione reductase. Plant Physiol. 59, 1011-1012. https://doi.org/10.1104/pp.59.5.1011.

Schlenk, D., Celander, M., Gallagher, E., George, S., James, M., Kullman, S., van den Huk, P., Willet, K., 2008. Biotransformation in fishes. In: Di Giulio, R., Hinton, D. (Eds.), The Toxicology of Fishes. CRC Press, New York, p. 1101.

Sephton, D.H., Haya, K., Martin, J.L., Legresley, M.M., Page, F.H., 2007. Paralytic shellfish toxins in zooplankton, mussels, lobsters and caged Atlantic salmon, Salmo salar, during a bloom of Alexandrium fundyense off Grand Manan Island. the Bay of Fundy 6, 745-758. https://doi.org/10.1016/j.hal.2007.03.002.

Silva, C.A., Oba, E.T., Ramsdorf, W.A., Magalhães, V.F., Cestari, M.M., Alberto, C., Ribeiro, O., Silva, H.C., Assis, D., 2011. First report about saxitoxins in freshwater fish Hoplias malabaricus through trophic exposure. Toxicon 57, 141-147. https://doi. org/10.1016/j.toxicon.2010.10.015.

Stephensen, E., Sturve, J., Förlin, L., 2002. Effects of redox cycling compounds on glutathione content and activity of glutathione-related enzymes in rainbow trout liver. Comp. Biochem. Physiol., C 133, 435-442. https://doi.org/10.1016/S15320456(02)00129-1.

Suárez-Isla, B.A., 2016. Marine and freshwater toxins. Mar. Freshw. Toxins 23-41. https://doi.org/10.1007/978-94-007-6419-4.
Testai, E., Buratti, F.M., Funari, E., Manganelli, M., Vichi, S., Arnich, N., Biré, R., Fessard, V., Sialehaamoa, A., 2016a. Review and Analysis of Occurrence, Exposure and Toxicity of Cyanobacteria Toxins in Food. EFSA supporting publication, p. 309.

Testai, E., Scardala, S., Vichi, S., Buratti, F.M., 2016b. Risk to human health associated with the environmental occurrence of cyanobacterial neurotoxic alkaloids anatoxins and saxitoxins. Crit. Rev. Toxicol. 46 (5), 385-419. https://doi.org/10.3109/ 10408444.2015.1137865.

Thottumkara, A.P., Parsons, W.H., Du Bois, J., 2014. Saxitoxin. Angew. Chem. Int. Ed. 53, 5760-5784. https://doi.org/10.1002/anie.201308235.

Torres, R., Pizarro, L., Csendes, A., 2007. Gtx 2/3 epimers permeate the intestine through a paracellular pathway. J. Toxicol. Sci. 32 (3), 241-248.

Van de Waal, D.B., Tillmann, U., Martens, H., Krock, B., van Scheppingen, Y., John, U., 2015. Characterization of multiple isolates from an Alexandrium ostenfeldii bloom in The Netherlands. Harmful Algae 49, 94-104. https://doi.org/10.1016/j. hal.2015.08.002.

Venturino, A., Anguiano, O.L., Gauna, L., Cocca, C., Bergoc, R.M., Pechen De D'Angelo, A.M., 2001. Thiols and polyamines in the potentiation of malathion toxicity in larval stages of the toad Bufo arenarum. Comp. Biochem. Physiol., C 130, 191-198. https://doi.org/10.1016/S1532-0456(01)00241-1.

Vieira, L.R., Gravato, C., Soares, A.M.V.M., Morgado, F., Guilhermino, L., 2009. Acute effects of copper and mercury on the estuarine fish Pomatoschistus microps: linking biomarkers to behaviour. Chemosphere 76, 1416-1427. https://doi.org/10.1016/j. chemosphere.2009.06.005.

White, A.W., 1980. Recurrence of kills of Atlantic Herring (Clupea harengus harengus) caused by dinoflagellate toxins transferred through herbivorous zooplankton. Can. J. Fish. Aquat. Sci. 37, 2262-2265. https://doi.org/10.1139/f80-271.

Who, 2019. Cyanobacterial toxins: saxitoxins. Guidel. Drink. Qual. Guidel. Safe Recreat. Water Environ. 1-19.

Wu, G., Fang, Y., Yang, S., Lupton, J.R., Turner, N.D., 2004. Glutathione metabolism and its Implications for health. J. Nutr. 134, 489-492. https://doi.org/10.1093/jn/ 134.3.489.

Xu, H., Ren, D., 2016. Lysosomal physiology. Annu. Rev. Physiol. 77, 57-80. https://doi. org/10.1146/annurev-physiol-021014-071649.Lysosomal.

Zamek-Gliszczynski, M.J., Hoffmaster, K.A., Nezasa, K.I., Tallman, M.N., Brouwer, K.L. R., 2006. Integration of hepatic drug transporters and phase II metabolizing enzymes: mechanisms of hepatic excretion of sulfate, glucuronide, and glutathione metabolites. Eur. J. Pharmaceut. Sci. 27, 447-486. https://doi.org/10.1016/j. ejps.2005.12.007.

Zar, J., 1999. Biostatistical Analysis, fourth ed. Prentice Hall. 